$\left.\begin{array}{c}\text { INTERNATIONAL JOURNAL OF } \\ \text { ORGANIZATIONAL LEADERSHIP }\end{array}\right) \begin{gathered}\text { INDUSTRIAL } \\ \text { MANAGEMENT } \\ \text { INSTITUTE }\end{gathered}$

\title{
Does organizational culture mediate the relationship between transformational leadership and organizational commitment?
}

\author{
Nor Hazana Abdullah*, Alina Shamsuddin, Eta Wahab
}

Faculty of Technology Management and Business, Universiti Tun Hussein Onn, Malaysia

\begin{tabular}{|c|c|}
\hline & ABSTRACT \\
\hline \multicolumn{2}{|l|}{ Keywords: } \\
\hline Transformational & $\begin{array}{l}\text { To date, the relationships among organizational culture, transformational leadership and } \\
\text { organizational commitment have been empirically investigated. However, majority of these }\end{array}$ \\
\hline Leadership, Organizational & studies have been focusing on direct effects of either transformational leadership or \\
\hline Commitment, Organizational & organizational culture on organizational commitment in large organizations. This approach \\
\hline Culture & $\begin{array}{l}\text { might not only hinder our understanding on real predictors of organizational commitment } \\
\text { but also obscure the presence of spurious relationships. Therefore, this study aims to } \\
\text { determine the mediating effect of organizational culture on the relationship between } \\
\text { transformational leadership and organizational commitment among small business } \\
\text { employees. An explanatory research design was used with cross-sectional survey as data } \\
\text { collection techniaue Once the composite reliability construct and convergent and }\end{array}$ \\
\hline Correspondence: & discriminant validity of the measurement constructs were established, a Partial Least Square \\
\hline hazana@uthm.edu.my & $\begin{array}{l}\text { Structural Equation Modeling (PLS-SEM) was run to analyze the structural model and the } \\
\text { mediating effect of organizational culture. The results showed that organizational culture } \\
\text { does not mediate the effect of transformational leadership on organizational commitment } \\
\text { among small business. This study cautions the generalization of findings obtained from } \\
\text { large organizations to be extended to small organizations. }\end{array}$ \\
\hline
\end{tabular}

(C)AIMI Journals

\section{Introduction}

Organizational commitment is an important predictor of intention to quit, which is invariably the best predictor of actual labor turnover (Law, 2005; Pao-Long, Ying-Chyi, \& Fei-Chun 2007; Trimble, 2006; Wagner, 2007). It, also, reflects loyalty and willingness to work 
towards organizational objectives and thus a good measure of organizational effectiveness. Organizational commitment is also associated with organizational citizenship behavior (LePine, Erez, \& Johnson, 2002; Meyer, Stanely, Herscovitch, \& Topolnytsky, 2002), low absenteeism (Sagie, 1998), performances at individual, team and organizational levels (Jaramillo, Mulki, \& Marshal, 2005; Neininger, Willenbrock, Kauffeld, \& Hensche, 2010; Steyrer, Schiffinger, \& Lang, 2008). Realizing the importance of organizational commitment to the organizations, numerous studies have been focusing on determining its predictors or antecedents ranging from organizational support (Celep \& Yilmazturk, 2012; Makanjee, Hartzer, \& Uys, 2006; Vandenberg, Bentein, \& Stinglhamber, 2004), compensation system (Lam and Zhang, 2003; Williamson, Burnett, \& Bartol, 2009), job satisfaction (Aghdasi, Kiamanesh, \& Ebrahim, 2011; Yang, 2010), socialization (Klein, Fan, \& Preacher, 2006), leadership (Emery \& Barker, 2007), and organizational culture (Gifford, Zammuto, \& Goodman, 2002). Recently, Morrow (2010) reviewed 58 longitudinal studies to unearth six broad categories of organizational commitment predictors, including socialization practices, organizational changes, human resources practices, interpersonal relations, and residual categories. Further scrutiny of these predictors revealed compelling components of both transformational leadership behavior and organizational culture. For example, newcomer socialization is a part of organizational culture development process (Schein, 1983) and perceived leaders and supervisors' ideal trait and abilities are commonly referred to transformational leadership components (Bass \& Avolio, 1997). Morrow's study is consistent with other studies that claimed transformational leadership and organizational culture to be the most influential predictors of organizational commitment (Emery \& Barker, 2007; Gregory et al., 2007; Sikorsa-Simmons, 2005).

Interestingly, majority of available empirical studies had focused on direct effects of either leadership or organizational culture on organizational commitment while none has attempted to investigate the mediating effect of organizational culture despite its compelling theoretical stances (Schein, 1991). According to Bass (1999), direct effects analysis is insufficient in understanding complex issues such as organizational commitment. He further asserted that mediation analysis is a key part of what has been called process analysis where the mechanism through which transformational leadership affects the employees' organizational commitment could be identified. Holbert and Stephenson (2002) affirmed the need for research to move beyond analyzing direct effects since only by analyzing the direct, indirect and total effects, better understanding on issues could be gained. 
Moreover, majority of these studies were also conducted in large organizations that have different characteristics compared to small business. Generalizations of such findings in the context of small business would provide simplistic and misleading view as small business' characteristics are significantly different from their larger counterparts (Wilson \& Bates, 2003). Therefore, this paper is aimed to determine the mediating effect of organizational culture on the relationship between transformational leadership and organizational commitment among small business.

In the following section, we discuss the relevant literature on transformational leadershipcommitment, organizational culture - commitment, transformational leadership-culture. Next, a conceptual framework including transformational leadership, organizational culture, and organizational commitment is proposed. Finally, a hypothesis regarding the mediating role of organizational culture is formulated.

\section{Transformational Leadership and Organizational Commitment}

Organizational commitment has been claimed to be the strongest effect of transformational leadership (Bass \& Riggio, 2006). Accordingly, empirical evidence on the positive effect of transformational leadership on organizational commitment has been consistent across studies. For example, Chen (2004) found that leadership, regardless of styles, would have some effects on the organizational commitment while Arnold, Barling, and Kelloway (2001), Pillai and Williams (2004), Shi (2004), Al-Ammaj (2000), Amoroso (2002) and Erkutlu (2008) found positive relationship between transformational leadership and organizational commitment.

Transformational leaders, through Idealized Influence and Inspirational Motivation, impart a sense of mission and bring about changes in the attitude in forms of enhanced organizational commitment (Bass \& Avolio, 1994; Kanungo, 1998). These leaders provide employees with greater opportunities for decision latitude, challenges, responsibility, as well as self-determination using individualized consideration. This in return, would result in employees who are more likely to reciprocate with higher levels of organizational commitment (Wayne, Shore, \& Liden, 1997). Transformational leaders also use Intellectual Stimulation to encourage their followers to take more responsibilities and autonomy. Bass and Avolio (1997) claimed that by encouraging employees to think critically and involving them in decision-making process, the leaders would inspire loyalty and organizational commitment (Walumbwa \& Lawler, 2003). Thus, this study hypothesized a significant 
positive relationship between transformational leadership and organizational commitment $\left(\mathrm{H}_{1}\right)$.

\section{Organizational Culture and Organizational Commitment}

The link between organizational culture and organizational commitment is theoretically driven from popular writings of Ouchi (1981), Peters and Waterman (1982) and Deals and Kennedy (1982). They suggested that organizational culture affects a range of organizational and individual outcomes including productivity, performance, commitment, and selfconfidence. This theoretical proposition has spurred many subsequent empirical studies to investigate the relationship between organizational culture and organizational commitment.

There are two major approaches adopted by researchers in investigating the relationship between organizational culture and organizational commitment. The first approach contends that there are a few types of organizational cultures, where one can compare which type of culture will have positive effects on organizational commitment. The second approach correlates cultural dimensions with the organizational commitment to see which cultural dimensions have significant relationships. There are compelling numbers of empirical studies that utilized the first approach (Gifford, Zammuto, \& Goodman, 2002; Rashid, Sambasivan, \& Johari, 2003; Shaw \& Reyes, 1992) while only a few studies such as by Chow, Harrison, McKinnon, and $\mathrm{Wu}(2001)$ use the second approach. Despite the different approaches, there is substantial evidence derived from both approaches that organizational culture is related to organizational commitment.

The positive relationship is based on the fact that organizational commitment is an elementary by-product of organizational culture. As members of the organizations internalize the shared basic values and assumptions, and identify themselves with the organizations, their organizational commitment is enhanced. Organizational culture that is characterized as collaborative, fraternal, cohesiveness; participative, consensual, constructive, and supportive is more likely to increase level of organizational commitment. Thus, the study hypothesized the positive relationship between organizational culture and organizational commitment $\left(\mathbf{H}_{2}\right)$.

\section{Transformational Leadership and Organizational Culture}

Unlike the transformational leadership-organizational commitment and organizational culture-organizational commitment studies, literatures examining the effect of leadership on organizational culture yield mixed results. Many studies have concentrated on organizational 
culture in relation to cultural change (Rashid, Sambasivan, \& Johari, 2003), performance (Denison, 2000), knowledge management (McDermott \& O’Dell, 2001; Ribiere \& Sitar, 2003), and organizational effectiveness (Smart, 2003), with limited empirical studies on leadership influence on organizational culture.

Nonetheless, anecdotal theoretical stance suggested that organizational culture is derived from leadership and affects its subsequent leadership-subordinates relationship (Bass \& Avolio, 1993; Schein, 1991, 1992). Schein $(1991,1992)$ in his seminal work, described the significant roles of leadership in the creation and management of organizational culture in entrepreneurial organizations. He stated that during the formation of organizations and its early life, leaders or founders dictate organizational culture through resolving the external adaptation and internal integration problems. Since founders or leaders are usually entrepreneurs who inhibit high level of self-confidence and determination, they impose strong assumptions to their founding organizations.

The dynamics of transformational leadership-organizational culture is further explained by Bass and Avolio (1994) in their article entitled transformational leadership and organizational culture. They claimed that organizational culture, which is shaped by transformational leadership, has a sense of purpose and a feeling of family. Transformational leaders act as role models that espouse organizational goals and encourage employee commitment to the organization's purpose and vision. In addition, the transformational leaders change the organizational culture by aligning it with a new vision and prepare it for desirable organizational change.

Despite the strong theoretical proposition, empirical studies revealed inconsistent findings. Although some researchers (Block ,2003; Choi and Sagas, 2005; \& Lucas and Valentine, 2002) found significant relationship between transformational leadership and organizational culture, Howard (2004) found only partial relationship while Ridgway (1998) found no relationship. Inconsistent results showed the need to further validate the relationship between transformational leadership and organizational culture especially in the context of small business. Thus, this study hypothesized a significant positive relationship between transformational leadership and organizational culture $\left(\mathbf{H}_{3}\right)$.

\section{Organizational Culture as Mediator}

Studies that include all the three variables in the context of small business, is almost nonexistent. Thus, drawing heavily from the upper echelon theory, this study postulates the 
pervasive effect of transformational leadership of the owner-managers on the organizational culture and eventually on the employees' commitment. According to Kilman (1984), situational force and key individuals shape organizational culture. The situational forces are the organization's mission, its setting and what is required for success, for example, quality, efficiency, reliability, customer service, innovation, hard work and loyalty. Despite the importance of situational forces, Kilman (1984) and Trice and Beyer (1993) viewed the actions of founders of organizations as more important. This is because these founders bring in their objectives, principles, values and behaviors that provide important clues to employees about what is really expected of all members. Sathe (1985) added that because the founders had the original idea, they typically have biases on how to have the idea fulfilled. Similarly, Robbins (1990) contended that founders are the ultimate source of organizational culture. Figure 1 shows the research framework. Thus, this study hypothesized that organizational culture mediates the relationship between transformational leadership and organizational commitment $\left(\mathbf{H}_{4}\right)$.

\section{Methodology}

\section{Data Collection}

The research design for this study was explanatory with survey as major data collection technique. The selection of the research design was based on the nature of the research objectives that involved hypothesis testing and the need to observe the phenomenon in its natural setting. Award-winning companies of enterprise 50 in manufacturing sector were invited to participate in the study. Seven award-winning companies out of eleven agreed to participate with a population of 449 employees. Based on Krejcie and Morgan's (1970) sampling size table, a sample size of 207 was derived to get $95 \%$ confidence level and $5 \%$ error. One hundred twelve respondents participated to yield a return rate of 54.1\%. According to Miller (1991), a return rate ranged from 30 percent to 50 percent is common in social science surveys and can be accepted while Roth and BeVier (1998) stated that a return rate ranged from 50 percent to 80 percent is considered as good response rates.

\section{Instruments}

Three established instruments which include leadership questionnaires (MLQ-5X), organizational culture survey (OCS) and organizational commitment questionnaire (OCQ) were used in this study. Multifactor leadership questionnaire (MLQ-5X) was used to measure 
transformational leadership while Denison's organizational culture survey (OCS) was used to measure organizational culture. Organizational commitment questionnaire (OCQ) was used to measure organizational commitment.

\section{Results}

This section presents the results in forms of validity and reliability of measurement model and hypothesis testing based on the structural model.

\section{Validity}

Prior to structural modeling, measurement model was tested in terms of its validity and reliability. Three measures of validity were used which include construct validity, convergent validity and discriminant validity. Construct validity specifies how well the results attained from the use of measure fit the theories around which the test is designed (Sekaran \& Bougie, 2010). Table 1 shows loadings and cross loadings of each item used in the study. A cut-off value of 0.5 as significant was used as suggested by Hair, Black, Babin, and Anderson (2010). It is evident that all loadings were above 0.5 demonstrating the construct validity of the measures.

Table 1

Loadings and Cross Loadings

\begin{tabular}{cccc}
\hline & Transformational Leadership & Organizational Culture & Organizational Commitment \\
\hline TL1 & 0.91 & 0.53 & 0.44 \\
TL2 & 0.91 & 0.57 & 0.60 \\
TL3 & 0.90 & 0.52 & 0.51 \\
TL4 & 0.85 & 0.58 & 0.54 \\
CUL1 & 0.37 & 0.66 & 0.54 \\
CUL2 & 0.54 & 0.91 & 0.67 \\
CUL3 & 0.52 & 0.90 & 0.63 \\
CUL4 & 0.61 & 0.88 & 0.73 \\
Com1 & 0.49 & 0.62 & 0.74 \\
Com2 & 0.45 & 0.59 & 0.79 \\
Com3 & 0.43 & 0.61 & 0.78 \\
Com4 & 0.45 & 0.62 & 0.77 \\
Com5 & 0.53 & 0.59 & 0.82 \\
Com6 & 0.42 & 0.60 & 0.76 \\
Com7 & 0.42 & 0.56 & 0.74 \\
Com8 & 0.46 & 0.48 & 0.74 \\
Com9 & 0.36 & 0.57 & 0.70 \\
\hline
\end{tabular}

Bold values are loadings for items that are above the recommended value of 0.5

Convergent validity of the measures was gauged by the factor loadings, composite reliability and average variance extracted (Hair, Black, Babin, \& Anderson, 2010). The loadings of all items exceeded the recommended value of 0.5 with the composite reliability 
values above the recommended value of 0.7 except for item CUL1 and the average variance extracted (AVE) greater than 0.5 (see Table 2).

Table 2

Results of Measurement Mode

\begin{tabular}{rcccc}
\hline Model Construct & Measurement Item & Loading & CR & AVA \\
\hline Transformational Leadership & TL1 & 0.915 & 0.944 & 0.807 \\
& TL2 & 0.919 & & \\
TL3 & TL4 & 0.901 & & \\
& CUL1 & 0.857 & 0.721 \\
CUL2 & 0.665 & & \\
Organizational Commitment Culture & CUL3 & 0.919 & & 0.586 \\
& CUL4 & 0.901 & & \\
& Com1 & 0.887 & & \\
& Com2 & 0.927 & & \\
& Com3 & 0.799 & & \\
& Com4 & 0.780 & & \\
& Com5 & 0.770 & & \\
& Com6 & 0.828 & & \\
& Com7 & 0.767 & & \\
& Com8 & 0.741 & & \\
& Com9 & 0.749 & & \\
\end{tabular}

Table 3 summarizes the results of the measurement model showing all the three constructs namely transformational leadership, organizational culture and organizational commitment as valid constructs.

Table 3

Summary Results of Model Construct

\begin{tabular}{|c|c|c|c|}
\hline Model Construct & Measurement Item & Standardized Estimates & T-value \\
\hline \multirow[t]{4}{*}{ Transformational Leadership } & TL1 & 0.91 & 36.92 \\
\hline & TL2 & 0.91 & 63.64 \\
\hline & TL3 & 0.90 & 37.75 \\
\hline & TL4 & 0.85 & 26.22 \\
\hline \multirow[t]{4}{*}{ Organizational Culture } & CUL1 & 0.66 & 5.30 \\
\hline & CUL2 & 0.91 & 53.97 \\
\hline & CUL3 & 0.90 & 43.07 \\
\hline & CUL4 & 0.88 & 38.93 \\
\hline \multirow[t]{9}{*}{ Organizational Commitment } & Com1 & 0.74 & 15.42 \\
\hline & Com2 & 0.79 & 15.45 \\
\hline & Com3 & 0.78 & 19.33 \\
\hline & Com4 & 0.77 & 13.86 \\
\hline & Com5 & 0.82 & 18.35 \\
\hline & Com6 & 0.76 & 15.21 \\
\hline & Com7 & 0.74 & 11.56 \\
\hline & Com8 & 0.74 & 10.38 \\
\hline & Com9 & 0.70 & 13.21 \\
\hline
\end{tabular}


Once the construct and the convergent validity of all measures were established, discriminant validity was examined. According to Compeau, Higgins, and Huff (1999), the average variance shared between each construct and its measures should be greater than the variance shared between construct and other constructs. The squared correlations of each construct as shown I Table 4 indicates that AVE for each construct is greater than the squared correlations of other constructs that implies adequate discriminant validity.

Table 4

Discriminant Validity of Constructs

\begin{tabular}{|c|c|c|c|}
\hline Constructs & Transformational Leadership & Organizational Culture & Organizational Commitment \\
\hline \multicolumn{4}{|l|}{ Transformational } \\
\hline Leadership & 0.80 & & \\
\hline $\begin{array}{l}\text { Organizational } \\
\text { Culture }\end{array}$ & 0.38 & 0.72 & \\
\hline $\begin{array}{c}\text { Organizational } \\
\text { Commitment }\end{array}$ & 0.34 & 0.59 & 0.58 \\
\hline
\end{tabular}

Diagonals (in bold) represent the AVE while other entries represent the squared correlations

Cronbach's alpha coefficient was used to determine the inter item consistency of the measurement items. Table 5 shows the alpha values along with the loading range of each construct. All items have alpha values more than 0.7 which is considered good (Nunnally \& Bernstein, 1994). In addition, results of composites reliability of all construct are all above 0.9 which is considered good (Fornell \& Larcker, 1981).

Table 5

Results of Reliability Test

\begin{tabular}{ccccc}
\hline Model Construct & Measurement Item & Cronbach's Alpha & Loading Range & Number of Items \\
\hline $\begin{array}{c}\text { Transformational } \\
\text { Leadership }\end{array}$ & TL1, TL2, TL3, TL4 & 0.92 & $0.85-0.91$ & 4 \\
$\begin{array}{c}\text { Organizational } \\
\text { Culture }\end{array}$ & CUL1, CUL2, CUL3, CUL4 & 0.86 & $0.66-0.91$ & 4 \\
& & & & $0.70-0.82$ \\
Organizational \\
Commitment & $\begin{array}{l}\text { Com1, Com2, Com3, } \\
\text { Com4, Com5, Com6, } \\
\text { Com7, Com8, Com9 }\end{array}$ & 0.91 & & 9 \\
\hline
\end{tabular}

Table 6 shows the path coefficients of the structural model. The structural coefficient between transformational leadership and organizational commitment is not significant $(t<1.96)$ with direct effect of 0.181 . Thus, $H_{1}$ is rejected. The structural coefficient between organizational culture and organizational commitment was $0.658(t>1.96)$. Therefore, $\mathrm{H}_{2}$ is accepted. Organizational culture is a significant predictor of organizational commitment with 
$61.3 \%$ of variance on organizational commitment can be explained by organizational culture. The structural coefficient between transformational leadership and organizational culture is significant with direct effect of $0.618(t>1.96)$. The $R^{2}$ indicates that $38.2 \%$ of variance of organizational culture can be explained by transformational leadership. Thus $\mathrm{H}_{3}$ is accepted.

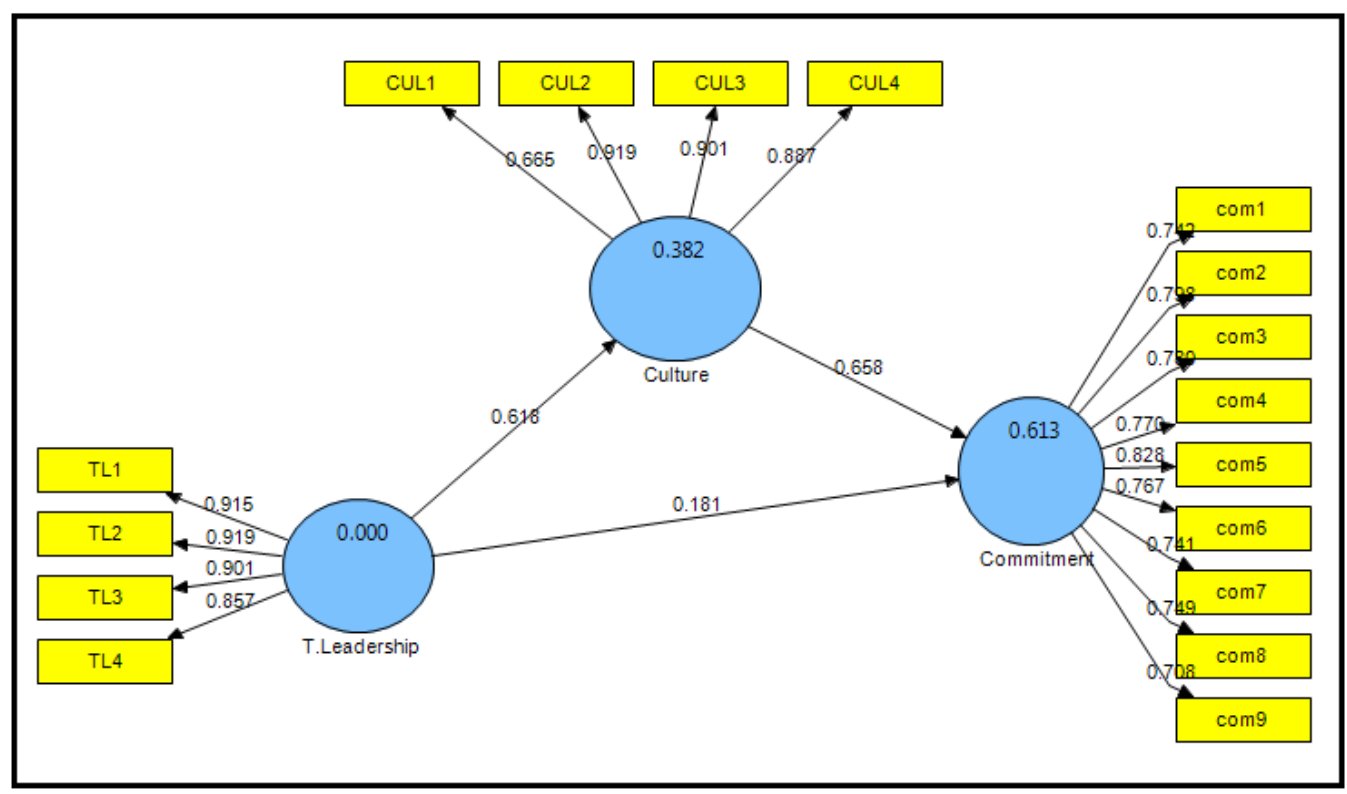

Figufigure 1. Structural path

Table 6

Path Coefficient and Hypothesis Testing

\begin{tabular}{ccccc}
\hline Hypothesis & Relationship & Coefficient & t- value & Supported \\
\hline $\mathrm{H}_{1}$ & $\mathrm{TL}$--> Commitment & 0.18 & 1.90 & NO \\
$\mathrm{H}_{2}$ & Culture --> Commitment & 0.65 & 8.34 & YES \\
$\mathrm{H}_{3}$ & $\mathrm{TL}->$ Culture & 0.61 & 9.35 & YES \\
$\mathrm{H}_{4}$ & $\mathrm{TL}-->$ Culture --> & 0.41 & & NO \\
& Commitment & & & \\
\hline
\end{tabular}

Since there is no significant relationship between transformational leadership and organizational commitment, the mediation effect is not observed based on Baron and Kenny's suggestion (1986).

\section{Discussion and Conclusion}

The objective of this study was to examine the mediating effect of organizational culture on the relationship between transformational leadership and organizational commitment among small business. Concerning its findings, there are two major conclusions that are worth to be 
highlighted. First, contrary to previous empirical evidence (Arnold, Barling, \& Kelloway, 2001; Erkutlu, 2008; Pillai \& Williams, 2004; Shi, 2004), the mediation effect of organizational culture fails to be observed. Secondly, this study lends support to the Upper Echelons Theory that claims pervasive influence of owner-manager on various organizational outcomes (Hambrick and Mason, 1984), Schein's contention that owner-manager are creators of organizational culture and Bass and Avolio's (1993) assertion that transformational leader is the 'giver' and the 'definer' of organizational culture. As organizational culture reflects many salient attributes and characteristics of the owner-managers,

\section{Implications}

This finding implies that transformational leadership is an important competency to be developed since it can influence organizational. Based on these findings, it is evident that leadership development is a critical area that needs to be addressed by both relevant authorities and industries to increase small business global competitiveness. More leadership training programs need to be developed to shape the present and future small business ownermanagers on how to develop competitive organizational culture in their organizations. Although a cultural change is a daunting task, the small business owner-managers are indeed the impetus to transform the culture of their organizations.

This study is among the first to study predictors of organizational commitment in the context of small business in Malaysia. It also provides empirical support on the mediating effect of organizational culture on the relationship between transformational leadership and organizational commitment that has not been tested in other studies. The inconsistent finding on the relationship between transformational leadership and organizational commitment might indicate the inappropriateness to generalize large business findings onto the small business. In terms of methodology, the use of PLS-SEM, which is claimed to be more robust compared to other multivariate techniques would lend credibility of the finding.

\section{Limitations}

The present study does not go without limitations. Perhaps the major limitation of this study is the small sample size. Although many efforts had been invested to increase number of participation and response rate, the final data collected remained low. However, this issue remains a significant hurdle for researchers in various disciplines in Malaysia. In addition, the participating companies were award-winners of enterprise 50 award that means that the 
findings might not be generable to large companies or mixed-performance small business in Malaysia. Furthermore, the relationship between transformational leadership, organizational culture, and organizational commitment might also be recursive. An area for future research is to replicate this study among mixed performing small business. Inclusion of other predictors would also elucidate the roles of other factors that could influence organizational commitment among small business employee. Qualitative approach to this study would provide a richer data in terms of how the small business owner-managers shape the organizational culture.

\section{References}

Aghdasi, S., Kiamanesh, A. R., \& Ebrahim, A. N. (2011). Emotional intelligence and organizational commitment: Testing the mediatory role of occupational stress and job satisfaction. Procedia: Social \& Behavioral Sciences, 29, 1965-1976.

Al-Ammaj, F. H. (2000). An investigation of leadership style and organizational commitment among Saudi public employees (Unpublished doctoral dissertation). Mississippi State University, United States.

Amoroso, P. F. (2002). The impact of principal's transformational leadership behaviors on teacher commitment and teacher job satisfaction (Unpublished Doctoral Dissertation). Seton Hall University, South Orange, New Jersey.

Arnold, K. A., Barling, J., \& Kelloway, E. K. (2001). Transformational leadership or iron cage: Which predicts trust, commitment and team efficacy? Leadership \& Organization Development Journal, 22(7), 315-320.

Baron, R. M., \& Kenny, D. A. (1986). The moderator-mediator variable distinction in social psychological research: Conceptual, strategic and statistical considerations. Journal of Personality \& Social Psychology, 51(6), 1173-1182.

Bass, B. M. (1999). On the taming of charisma: A reply to Janice Beyer. Leadership Quarterly, 10 (4), 541-533.

Bass, B. M., \& Avolio, B. J. (1993). Transformational leadership and organizational culture. Public Administration Quarterly, 17(1), 112-122.

Bass, B. M., \& Avolio, B. J. (1994). Improving organizational effectiveness through transformational leadership. Thousand Oaks, CA: Sage Publication.

Bass, B. M., \& Avolio, B. J. (1997). Full range leadership development: Manual for multifactor leadership questionnaires. Redwood City, CA: Mind garden.

Bass, B. M., \& Riggio, R. E. (2006). Transformational leadership ( $2^{\text {nd }}$ ed.). Mahwah, NJ: Lawrence Erlbaum Associates.

Block, L. (2003). The leadership-culture connection: An exploratory investigation. Leadership \& Organization Development Journal, 24(6), 318-334.

Celep, C., \& Yilmazturk, O. E. (2012). The Relationship among organizational trust, multidimensional organizational commitment and perceived organizational support in educational organizations. Procedia-Social \& Behavioral Sciences, 46, 5763-5776.

Chen, L. Y. (2004). Examining the effect of organizational culture and leadership behaviors on organizational commitment, job satisfaction, and job performance at small and middle-sized firms of Taiwan. Journal of American Academy of Business, 5(1/2), 432-438.

Choi, J. H., \& Sagas, M. (2005). The impact of leadership on organizational culture in NCAA division I and II institution. Paper to be presented at the annual conference of the North American Society for Sport Management, Regina, Canada.

Chow, C. W., Harrison, G. L., Mckinnon, J. L., \& Wu, A. (2001). Organizational culture: Association with affective commitment, job satisfaction, propensity to remain and information sharing in a Chinese cultural context. CIBER working paper, San Diego State University.

Compeau, D., Higgins, C. A., \& Huff, S. (1999). Social cognitive theory and individual reactions to computing technology: A longitudinal study. MIS Quarterly, 23(2), 145-158

Deals, T. E., \& Kennedy, A. A. (1982). Corporate cultures: The rites and rituals of corporate life ( $1^{\text {st }}$ ed.). Reading, MA: Addison-Wesley. 
Denison, D. R. (2000). Organizational culture: Can it be a key lever for driving organizational change? In S. Cartwright \& C. Cooper (Eds.). The handbook of organizational culture. London: John Wiley \& Sons.

Emery, C. R., \& Barker, K. J. (2007). The effect of transactional and transformational leadership styles on the organizational commitment and job satisfaction of customer contact personnel. Journal of Organizational Culture, Communications \& Conflict, 11(1), 77-90.

Erkutlu, H. (2008). The impact of transformational leadership on organizational and leadership effectiveness: The Turkish case. Journal of Management Development, 27(7), 708-726.

Fornell, C., \& Larcker, D. F. (1981). Evaluating structural equation models with unobservable variables and measurement errors. Journal of Marketing Research, 18(1), 39-50.

Gifford, B. D., Zammuto, R. F., \& Goodman, E. A. (2002). The relationship between hospital unit culture and nurses' quality of work life. Journal of Healthcare Management, 47(1), 13-25.

Gregory, D. M., Way, C. Y., LeFort, S., Barrett, B. J., \& Parfrey, P. S. (2007). Predictors of registered nurses' organizational commitment and intent to stay. Health Care Management, 32(2), 119-127.

Hair, J. F., Black, W. C., Babin, B. J., \& Anderson, R. E. (2010). Multivariate data analysis (7 ${ }^{\text {th }}$ ed.). Upper Saddle River, NJ: Prentice Hall.

Hambrick, D. C., \& Mason, P. A. (1984). Upper echelons: The organization as a reflection of its top managers. Academy of Management Review, 9(2), 193-206.

Holbert, R. L., \& Stephenson, M. T. (2002). Structural equation modeling in the communication sciences, 1995-2000. Human Communication Research, 28(4), 531-551.

Howard, M. P. (2004). A study on the relationship between transformational leadership and organizational culture (Unpublished doctorial dissertation). Western Michigan University, Michigan.

Jaramillo, F., Mulki, J. P., \& Marshall, G. W. (2005). A meta-analysis of the relationship between organizational commitment and salesperson job performance: 25 years of research. Journal of Business Research, 58(6), 705-714

Kanungo, R. N. (1998). Leadership in organizations: Looking ahead to the 21st century. Canadian Psychology, 39(1-2), 7182.

Klein, H. J., Fan, J., \& Preacher, C. J. (2006). The effects of early socialization experiences on content mastery and outcomes: A mediational approach. Journal of Vocational Behavior, 68(1), 96-115.

Kilman, R. H. (1984). Beyond the quick fix: Managing five tracks to organizational success. San Francisco: Jossey-Bass.

Krejcie, R. V., \& Morgan, D. W. (1970). Determining sample size for research activities. Educational \& Psychological Measurement, 30(3), 607-610.

Lam, T., \& Zhang, H. Q. (2003). Job satisfaction and organizational commitment in the Hong Kong fast food industry. International Journal of Contemporary Hospitality Management 15(4), 214-220.

Law, D. W. (2005). Interactive organizational commitment and hardiness in public accountant's turnover. Managerial Auditing Journal, 20(4), 383-393.

LePine, J. A., Erez, A., \& Johnson, D. E. (2002). The nature and dimensionality of organizational citizenship behavior: A critical review and meta-analysis. The Journal of Applied Psychology, 87(1), 52-65.

Lucas, S. E., \& Valentine, J. W. (2002). Transformational leadership: Principals, leadership teams and school culture. Paper presented at the Annual meeting of the American Educational Research Association, New Orleans.

Makanjee, C. R., Hartzer, Y. F., \& Uys, I. L. (2006). The effect of perceived organizational support on organizational commitment of diagnostic imaging radiographers. Radiography, 12(2), 118-126.

McDermott, R., \& O’Dell, C. (2001). Overcoming cultural barriers to sharing knowledge. Journal of Knowledge Management, 5(1), 76-85.

Meyer, J. P., Stanley, D. J., Herscovitch, L., \& Topolnytsky, L. (2002). Affective, continuance, and normative commitment to the organization: A meta-analysis of antecedents, correlates, and consequences. Journal of Vocational Behavior, 61(1), $20-52$.

Miller, D. C. (1991). Handbook of research design and social measurement (5th ed.). Newbury Park, CA: Sage Publications.

Morrow, P. C. (2010). Managing organizational commitment: Insights from longitudinal research. Journal of Vocational Behavior, 79(1), 18-35.

Neininger, A., Willenbrock, N. L., Kauffeld, S., \& Hensche, A. (2010). Effects of team and organizational commitment: A longitudinal study. Journal of Vocational Behavior, 76(3), 567-579.

Nunnally, J. C., \& Bernstein, I. H. (1994). Psychometric theory ( $3^{\text {rd }}$ ed.). New York: McGraw-Hill. 
Ouchi, W. G. (1981). Theory Z: How American business can meet the Japanese challenge. Reading, MA: Addison-Wesley.

Pao-Long, C., Ying-Chyi, C., \& Fei-Chun, C. (2007). Career needs, career development programmes, organizational commitment and turnover intention of users in Taiwan. Journal of Nursing Management, 15(8), 801-810.

Peters, T. J., \& Waterman, R. H. (1982). In search of excellence: Lessons from America's best-run companies. New York: Harper Collins Publishers.

Pillai, R., \& Williams, E. A. (2004). Transformational leadership, self-efficacy, group cohesiveness, commitment, and performance. Journal of Organizational Change Management, 17(2), 144-159.

Rashid, M. Z. A., Sambasivan, M., \& Johari, J. (2003). The Influence of corporate culture and organizational commitment on performance. Journal of Management Development, 22(8), 708-728.

Ribiere, V. M., \& Sitar, A. S. (2003). Critical role of leadership in nurturing a knowledge-supporting culture. Knowledge Management Research \& Practice, 1(1), 39-48.

Ridgway, K. A. (1998). The relationship of leadership practices and cultural values to organizational effectiveness in small organizations (Unpublished doctorial dissertation). Kent State University, United States.

Robbins, S. P. (1990). Organization theory: Structure, designs and applications ( ${ }^{\text {rd }}$ ed.). New Jersey: Prentice Hall.

Roth, P. L., \& BeVier, C. A. (1998). Response rates in HRM/OB survey research: Norms and correlates, 1990-1994. Journal of Management, 24(1), 97-117.

Sagie, A. (1998) Employee absenteeism, organizational commitment, and job satisfaction: Another look. Journal of Vocational Behavior, 52(2), 156-171.

Sathe, V. (1985). Culture and related corporate realities: Text, cases and readings on organizational entry, establishment and change. Homewoods, IL: Irwin.

Schein, E. (1991). Coming to a new awareness of organizational culture. In D. A. Kolb, I. M. Rubin and J. S. Osland (Eds.). The organizational behavior reader. Englewood Cliffs, NJ: Prentice Hall.

Schein, E. (1992). Organizational culture and leadership (2 ${ }^{\text {nd }}$ ed.). San Francisco, CA: Jossey-Bass.

Schein, E. (1983). The role of the founder in creating organizational culture. Organizational Dynamics, 12(1), 13-28.

Schein, E. (2004). Organizational culture and leadership ( ${ }^{\text {rd }}$ ed.). San Francisco: Jossey-Bass.

Sekaran, U., \& Bougie, R. (2010). Research methods for business: A skill building approach (5 ${ }^{\text {th }}$ ed.). West Sussex, UK: John Wiley \& Sons.

Shaw, J., \& Reyes, P. (1992). School cultures: Organizational value orientation and commitment. Journal of Educational Research, 85(5), 295-302.

Shi, K. (2004). The role of collective efficacy in the relations between transformational leadership and work outcomes. Journal of Occupational and Organizational Psychology, 77(4), 515-530.

Sikorska-Simmons, E. (2005). Predictors of organizational commitment among staffs on assisted living. The Gerontologist, 45(2), 196-205.

Smart, J. C. (2003). Organizational effectiveness of 2-year colleges: The centrality of cultural and leadership complexity. Research in Higher Education, 44(6), 673-703.

Steyrer, J., Schiffinger, M., \& Lang, R. (2008). Organizational commitment: A missing link between leadership behavior and organizational performance? Scandinavian Journal of Management, 24(4), 364-374.

Trice, H. M., \& Beyer, J. M. (1993). The cultures of work organizations. Englewood Cliffs, New Jersey: Prentice Hall.

Trimble, D. E. (2006). Organizational commitment, job satisfaction and turnover intention among missionaries. Journal of Psychology \& Theology, 34(4), 349-360.

Vandenberge, C., Bentein, K., \& Stinglhamber, F. (2004). Affective commitment to organization, supervisor, and work group: Antecedents and outcomes. Journal of Vocational Behavior, 15(6), 535-547.

Wagner, C. M. (2007). Organizational commitment as a predictor variable in nursing turnover research: Literature review. Journal of Advanced Nursing, 60(3), 235-247.

Walumbwa, F. O., \& Lawler, J. J. (2003). Building effective organizations: Transformational leadership, collectivist orientation, work-related attitudes, and withdrawal behaviors in three emerging economies. International Journal of Human Resource Management, 14(7), 1083-1101.

Wayne, S., Shore, L., \& Liden, R. (1997). Perceived organizational support and leader-member exchange: A social exchange perspective. Academy of Management Journal, 40(1), 82-111. 
Williamson, I. O., Burnett, M. F., \& Bartol, K. M. (2009). The interactive effect of collectivism and organizational rewards on affective organizational commitment. Cross Cultural Management: An International Journal, 16(1), $28-43$.

Wilson, P., \& Bates, S. (2003). The essential guide to managing small business growth. West Sussex, UK: John Wiley \& Sons.

Yang, J. T. (2010). Antecedents and consequences of job satisfaction in the hotel industry. International Journal of Hospitality Management, 29(4), 609-619. 